\title{
Penerapan 5S (Seiri, Seiton, Seiso, Seiketsu, Shitsuke) Pada Area Kerja Sebagai Upaya Peningkatan Produktivitas Kerja (Studi Kasus Di CV Widjaya Presisi)
}

\author{
Muhammad Reza ${ }^{1}$, Hery Hamdi Azwir ${ }^{2}$ \\ 1,2)Industrial Engineering Department, Faculty of Technology, President University \\ Jababeka Education Park, Jl. Ki Hajar Dewantara Kota Jababeka, Bekasi 17550, Indonesia \\ Email: ${ }^{1}$ rezapresuniv16@gmail.com, ${ }^{2}$ hery.azwir@president.ac.id
}

\begin{abstract}
Abstrak
CV Widjaya Presisi merupakan industri kecil menengah yang bergerak dalam bidang jasa industri dengan produk utamanya adalah special tool otomotif/electronic, dies, jig fixture, stamping, machining fabrication. Temuan masalah di area kerja ada sisa-sisa material yang tidak dihilangkan sehingga ruang pekerja sempit dan tidak ada manajemen dan pengawas yang mengatur lingkungan kerja dan keselamatan kerja. Penelitian ini bertujuan untuk mengimplementasikan rancangan $5 \mathrm{~S}$ terhadap kondisi yang ada. Penelitian ini menggunakan metode kualitatif, yaitu metode $5 \mathrm{~S}$. Tahap seiri dirancangkan dengan memilah peralatan yang penting, sangat penting, tidak penting dan sangat tidak penting. Tahap seiton dirancangkan dengan menata barang sesuai jenis barang. Tahap seiso dirancangkan dengan membuat area-area pembersihan. Tahap seiketsu dirancangkan dengan memberikan kontrol visual berupa pelabelan, pemberian tanda, dan papan area. Tahap shitsuke dirancangkan dengan melakukan kegiatan dengan menjadikan $5 \mathrm{~S}$ sebagai aturan kedalam sistem kegaiatan standar perusahaan. Setelah dilakukannya perbaikan, waktu kerja dapat di optimalkan dari 840 menit menjadi 810 menit atau mencapai penurunan sebesar 4\% dari waktu kerja. rata-rata produktivitas kerja pada bulan Maret 2019 dan April 2019 sebesar 99,5\% dimana pada bulan februari 2019 tingkat produktivitas hanya sebesar 57\% dan mengalami kenaikan yang signifikan pada bulan Maret 2019 sebesar 99\% dan bulan April 2019 sebesar 100\%.
\end{abstract}

Kata Kunci: 5S, Produktivitas Kerja, Waste, Seven Tools, Efisiensi Waktu.

\begin{abstract}
CV Widjaya Presisi is a small and medium industry engaged in industrial services with its main products being automotive / electronic special tools, dies, jig fixture, stamping, and fabrication. The findings of the problem in the work area are remnants of material that is not removed so that the working space is narrow and no management and supervisors regulate the work environment and work safety. This study aims to implement the $5 \mathrm{~S}$ design to existing conditions. This study uses a qualitative method, namely the $5 \mathrm{~S}$ method. The seiri stage is designed by sorting out the equipment that is important, very important, not important and very insignificant. Seiton stage is designed by arranging goods according to the type of goods. The seiso stage is designed by making cleaning areas. The seiketsu stage is designed by providing visual control in the form of labeling, marking, and area boards. The Shitsuke stage is designed by doing activities by making $5 \mathrm{~S}$ as a rule into the company's standard activity system. After repairs, working time can be optimized from 840 minutes to 810 minutes or a decrease of $4 \%$ from work time. The average work productivity in March 2019 and April 2019 amounted to 99.5\% where in February 2019 the productivity level was only 57\% and experienced a significant increase in March 2019 by $99 \%$ and April 2019 by 100\%.
\end{abstract}

Keywords: 5S, Work Productivity, Waste, Seven Tools, Time Efficiency.

\section{Pendahuluan}

Perusahaan merupakan suatu kumpulan dari fungsi-fungsi manajemen dan kumpulan dari orang-orang yang terlibat dalam suatu kegiatan untuk mencapai suatu tujuan yang telah ditetapkan sebelumnya. Prakteknya, perusahaan membutuhkan sumber daya untuk menjalankan kegiatan bisnis. Salah satu sumber daya yang diperlukan untuk mengelola kegiatan bisnis suatu perusahaan adalah sumber daya manusia (SDM). SDM menjadi sangat penting perannya karena tanpa unsur ini perusahaan tidak akan dapat mencapai tujuan yang telah ditetapkan (Purwanggono, et al, 2014).

Berdasarkan pengamatan selama jam kerja, di CV Widjaya Presisi pada area kerja ada sisa-sisa material yang tidak disingkirkan sehingga membuat ruang kerja para pekerja menjadi sempit dan membahayakan pekerja tersebut. Selain itu, tidak ada manajemen dan pengawas yang bertugas mengatur lingkungan kerja dan keselamatan kerja. Tidak ada penempatan yang jelas yang membuat area kerja menjadi tidak rapi dan pekerja merasa kesulitan untuk menemukan yang dicarinya, hal ini mengakibatkan terjadinya pemborosan waktu pada saat melakukan kegiatan kerja. Dalam hal aspek keamanan, area kerja yang tidak rapi ini dapat menyebabkan potensi bahaya seperti tergelincir atau tersandung. Selain itu, masih kurangnya kepedulian 
untuk memperhatikan penggunaan alat pelindung diri (APD). Masalah-masalah ini secara tidak langsung dapat mengurangi produktivitas dan efisiensi dalam pekerjaan.

Berdasarkan observasi yang telah dilakukan sesuai permasalahan diatas dapat diketahui bahwa untuk memudahkan proses pekerjaan perlu perbaikan pada kondisi tempat kerja yang sesuai pada lingkungan kerja. Salah satu cara yang dapat digunakan untuk menciptakan lingkungan kerja yang nyaman dan tertib adalah dengan mengimplementasikan program 5S (Seiri, Seiton, Seiso, Seiketsu, Shitsuke) secara benar dengan menemukan hal-hal yang penting dari tempat kerja untuk ditingkatkan dan hal-hal yang kurang penting untuk disingkirkan atau dibuang supaya nyaman selama proses produksi berlangsung dan dapat meningkatkan produktivitas karyawan.

Dengan dilakukannya perbaikan di tempat kerja, diharapkan dapat meningkatkan penilaian pelanggan terhadap produk dan layanan yang dihasilkan menjadi lebih baik dan meningkatkan produktivitas serta efisiensi dalam bekerja pada lingkungan kerja CV Widjaya Presisi.

\section{Metode}

\subsection{Metode 5S}

Metode 5S (Seiri, Seiton, Seiso Seiketsu, dan Shitsuke) ini pertama kali muncul pada tahun 1980an yang digagas oleh Takashi Osada. Metode $5 \mathrm{~S}$ sebagaimana diperlihatkan dalam Gambar 1, merupakan sebuah metode yang dapat digunakan untuk tujuan menciptakan dan menjaga kualitas lingkungan kerja dalam organisasi. Pengertian falsafah 5S menurut (Risma, 2016) yaitu:

1. Seiri, yaitu menyisihkan barang yang tidak diperlukan dengan yang perlu atau menyisihkan dan membuang barang yang tidak perlu di tempat kerja.

2. Seiton (susun), yaitu menata alat-alat kerja yang digunakan dengan rapi dan benar-benar menghilangkan kegiatan mencari agar alat-alat dapat mudah ditemukan dengan cepat.

3. Seiso, yaitu memelihara kebersihan tempat kerja.

4. Seiketsu, yaitu mempertahankan seiri, seiton, dan seiso agar dapat berlangsung terus-menerus.

5. Shitsuke, yaitu sebagai suatu kedisiplinan dan benar-benar menjadi kebiasaan, sehingga pekerja terbiasa menaati peraturan dan diadakan penyuluhan terhadap pekerja untuk bekerja secara profesional.

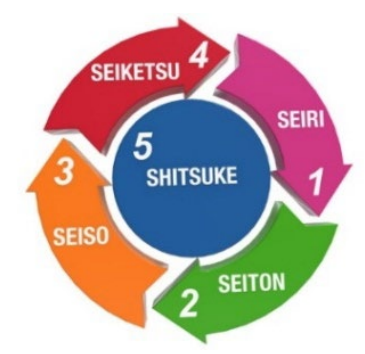

Gambar 1. Siklus 55

Sumber: konsultantrainingiso.com

Widianti (2015), menjelaskan bahwa $5 S$ juga bertujuan untuk menjaga lingkungan kerja tetap aman, bersih, nyaman dan kondusif. Menyatakan bahwa $5 \mathrm{~S}$ memiliki hubungan yang positif terhadap kualitas dan produktivitas. Apabila metode $5 \mathrm{~S}$ diterapkan secara benar maka akan diperoleh dampak positif terhadap perusahan yaitu (Listiani, 2014):

1. Setiap orang akan mampu menemukan masalah lebih cepat.

2. Setiap orang akan memberikan perhatian dan penekanan pada tahap perencanaan.

3. Mendukung cara berpikir yang berorientasi pada proses.

4. Setiap orang akan berkonsentrasi pada masalah-masalah yang lebih penting dan mendesak untuk diselesaikan.

5. Setiap orang akan berpartisipasi dalam membangun sistem yang baru.

6. Meminimumkan potensi terjadinya:

- Accident (kecelakaan kerja)

- Breakdown (gangguan kerusakan)

- Cost (biaya)

- Defect (produk cacat)

7. Meningkatkan efisiensi dan semangat kerja.

8. Organisasi yang siap mengikuti perubahan sesuai arahan startegi pimpinan. 


\subsection{Produktivitas}

Produktivitas adalah perbandingan antara total output barang dibagi dengan input yang meliputi sumber daya seperti tenaga kerja dan modal (Haizer, et al, 2014). Usaha peningkatan produktivitas menjadi perhatian dari para manajer atau pimpinan organisasi, meskipun demikian pada dasarnya para manajer atau para pimpinan organisasi itu hanya merupakan penanggung jawab dan pelaksanaan usaha peningkatan produktivitas. Gagasan dan kebijakan serta tanggung jawab akhir sebenarnya adalah terletak pada pimpinan puncak suatu organisasi. Faktor-faktor penentu keberhasilan peningkatan produktivitas menurut Siagian, (2014) yaitu diantaranya: 1) Perbaikan terus menerus yaitu upaya meningkatkan produktivitas kerja salah satu implementasinya ialah bahwa seluruh komponen harus melakukan perbaikan secara terus-menerus. 2) Peningkatan mutu hasil pekerjaan yang dilaksanakan oleh semua komponen dalam organisasi. 3) Pemberdayaan sumber daya manusia. 4) Filsafat organisasi yang sesungguhnya titik tolak perumusan etos kerja bersifat filsafat yang pada mulanya mungkin dirumuskan oleh para pendiri (founding father) organisasi yang bersangkutan. Untuk menghitung Rasio Produktivitas kerja dalam produksi dapat dicari melalui:

$$
\text { Produktivitas }=\frac{\text { output }}{\text { Input }} \times 100 \%
$$

Keterangan:

Input: Sumber-sumber daya yang dipergunakan untuk menghasilkan suatu Output.

Output: Hasil yang dicapai.

\subsection{Diagram Sebab Akibat (Fishbone Diagram)}

Heizer dkk. (2017) menyatakan bahwa diagram ini disebut juga diagram tulang ikan (Fishbone Chart) dan berguna untuk memperlihatkan faktor-faktor utama yang berpengaruh pada kualitas dan mempunyai akibat pada masalah yang kita pelajari, selain itu kita juga dapat melihat faktor-faktor yang lebih terperinci yang berpengaruh dan mempunyai akibat pada faktor utama tersebut yang dapat kita lihat pada panah-panah yang berbentuk tulang ikan pada diagram fishbone tersebut. Prinsip yang digunakan untuk membuat diagram sebab akibat ini adalah sumbang saran atau brainstorming. Faktor-faktor penyebab utama dalam diagram sebab akibat ini dapat dikelompokkan dalam: 1). Material (bahan baku); 2). Machine (mesin); 3). Man (tenaga kerja); 4). Method (metode); dan 5). Environment (lingkungan). Contoh dari diagram fishbone dapat dilihat dalam Gambar 2.



\subsection{Metode $5 \mathrm{~W}+1 \mathrm{H}$}

Perancangan pada tahap Improve dilakukan dengan cara melalui tahap-tahap merancang metode $5 \mathrm{~W}-1 \mathrm{H}$ (What-tujuan, Why-alasan kegunaan, Where-lokasi, When-kapan, Who-orang, dan Howmetode).

a. Improve pada faktor Man: ditentukan apakah tujuan Improve pada faktor Man, alasan kegunaannya, lokasi, sekuens, dan bagaimana caranya.

b. Improve pada faktor Machine: ditentukan apakah tujuan Improve pada faktor Machine, alasan kegunaannya, lokasi, sekuens, dan bagaimana caranya.

c. Improve pada faktor Material: ditentukanapakah tujuan Improve pada faktor Material, alasan kegunaannya, lokasi, sekuens, dan bagaimana caranya.

d. Improve pada faktor Method: ditentukan apakah tujuan Improve pada faktor Method, alasan kegunaannya, lokasi, sekuens, dan bagaimana caranya.

e. Improve pada faktor Media: ditentukan apakah tujuan Improve pada faktor media, alasan kegunaannya, lokasi, sekuens, dan bagaimana caranya. 


\subsection{Metodologi}

Berikut adalah diagram alir tentang cara membuat langkah-langkah penelitian dapat disajikan pada Gambar 3.

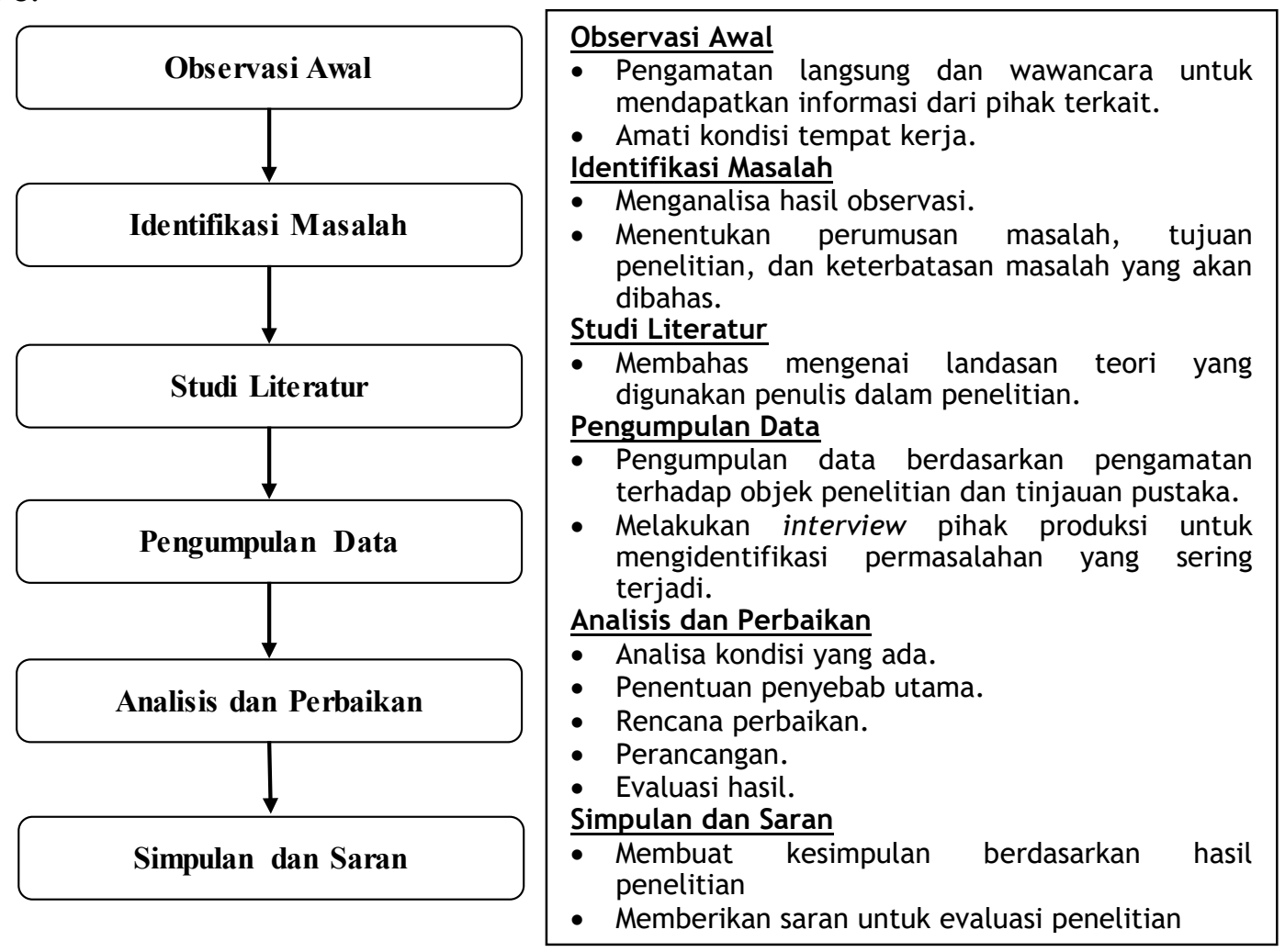

Gambar 3. Metodologi Penelitian

\subsubsection{Observasi Awal}

Langkah awal yang dilakukan dalam penelitian ini adalah observasi perusahaan. Pada langkah ini wawancara dilakukan langsung dengan Manajer CV Widjaya Presisi dan juga karyawan lainnya dengan tujuan mengetahui kondisi perusahaan saat ini. Kemudian melakukan pengamatan kondisi awal di lingkungan kerja CV Widjaya Presisi yang berkaitan dengan program 5S. Misalnya menyangkut keberadaan barangbarang/peralatan, efektifitas pemanfaatan peralatan kerja, kebersihan dan kerapihan lingkungan kerja. Hal ini dimaksudkan agar perancangan dan implementasi program tersebut dapat dilaksanakan dengan baik.

\subsubsection{Identifikasi Masalah}

Dari hasil pengamatan awal diperoleh berbagai masalah, misalnya penemuan ruang kerja yang tidak tertata dengan baik, keberadaan barang/peralatan kerja yang sudah tidak digunakan di ruang kerja dan kebersihan yang belum optimal di beberapa tempat. Dengan kondisi tersebut implementasi $5 \mathrm{~S}$ diharapkan dapat mengatasi masalah tersebut. Oleh karena itu penelitian difokuskan pada penerapan 5S. langkah selanjutnya menentukan rumusan masalah dari latar belakang yang telah dijelaskan. Kemudian tujuan dari rumusan masalah dapat diketahui dari hasil penelitian yang akan menjawab semua rumusan masalah. Batasbatas masalah kemudian ditentukan sehingga penelitian tidak keluar dari batas yang ditentukan.

\subsubsection{Studi Literatur}

Studi literatur berisi teori-teori yang akan berfungsi sebagai dasar untuk penelitian dan sebagai informasi untuk membantu memecahkan masalah. Landasan teori berasal dari referensi dalam bentuk buku dan jurnal yang berkaitan dengan penelitian yang sedang dilakukan. Pada tahap ini berbagai teori yang berkaitan dengan $5 \mathrm{~S}$ digunakan sebagai panduan dan landasan pemikiran dalam pemrosesan data serta landasan teoritis dalam pemecahan masalah.

\subsubsection{Pengumpulan Data}


Pengumpulan data dalam penelitian dilakukan dengan cara observasi lapangan, wawancara dengan karyawan, dan data yang tersedia dalam dokumen di perusahaan. Untuk memfasilitasi pemaparan suatu kondisi dari data yang dikumpulkan, itu ditetapkan dalam bentuk tabel.

\subsubsection{Analisis dan Perbaikan}

Dalam tahap ini dilakukan analisis dengan membandingkan kondisi saat ini dengan usulan dari perancangan dan identifikasi permasalahan dengan menggunakan salah satu dasar dari seven tools dimana pendekatan ini dapat mendefinisikan masalah, mengumpulkan data, mengidentifikasi penyebab yang mungkin, identifikasi akar masalah, pengajuan dan implementasi solusi. Data pendukung dari rencana usulan perancangan $5 \mathrm{~S}$ ini dengan melakukan data observasi meliputi data primer dan sekunder, dengan seiri (pemilahan) mengidentifikasi, memilah, memisahkan unit berdasarkan klasifikasi kondisi unit yaitu baik, perbaikan dan kondisi rusak, seiton (penataan) dengan menempatkan unit pada lokasi yang tepat dan diberi kodefikasi menurut kondisi unit, seiso (pembersihan) dengan membersihkan semua unit sesuai dengan karakteristik unit, seiketsu (perawatan) dengan melakukan cleaning (pembersihan); memeriksa Inspection dan kegiatan perbaikan, shitsuke dengan melakukan kegiatan yang menjadikan $5 \mathrm{~S}$ sebagai aturan kedalam sistem kegaiatan standar perusahaan yaitu Standard Operating Procedure (SOP) dan untuk memastikan program $5 S$ dilakukan dengan benar dan efektif maka dilakukan evaluasi.

\subsubsection{Simpulan dan Saran}

Sebagai tahap akhir dalam penelitian ini dibuat simpulan yang menyeluruh dari hasil evaluasi perbaikan yang diperoleh berdasarkan hasil penelitian yang telah dilakukan dan memberikan saran konstruktif untuk lebih meningkatkan implementasi 5S pada penelitian selanjutnya di CV Widjaya Presisi.

\section{Hasil dan Pembahasan}

CV Widjaya Presisi akan menerima order dari customer setiap sebulan sekali pada akhir bulan sebelumnya. Setelah menerima order dari customer, CV Widjaya presisi akan mengirimkan beberapa pilihan material yang ingin digunakan customer untuk produk yang dipesan. Untuk memenuhi permintaan tersebut CV Widjaya Presisi, menyiapkan material 2 hari sebelum proses produksi dan memastikan bahwa material tersebut dalam kondisi "OK". Setelahnya, CV Widjaya Presisi akan menyimpan material tersebut ke dalam gudang. Ketika akan di proses, maka CV Widjaya Presisi harus menerapkan aturan FIFO (First In First Out) sehingga material dapat terhindar dari korosi apabila disimpan terlalu lama karena material terbuat dari besi atau logam. Apabila sudah memenuhi kualitas maka akan dilakukan proses packing menggunakan pallet box kayu. Kemudian CV Widjaya Presisi akan mengirim sesuai dengan jadwal pengiriman yang telah ditentukan oleh customer.

\subsection{Analisis Diagram Fishbone}

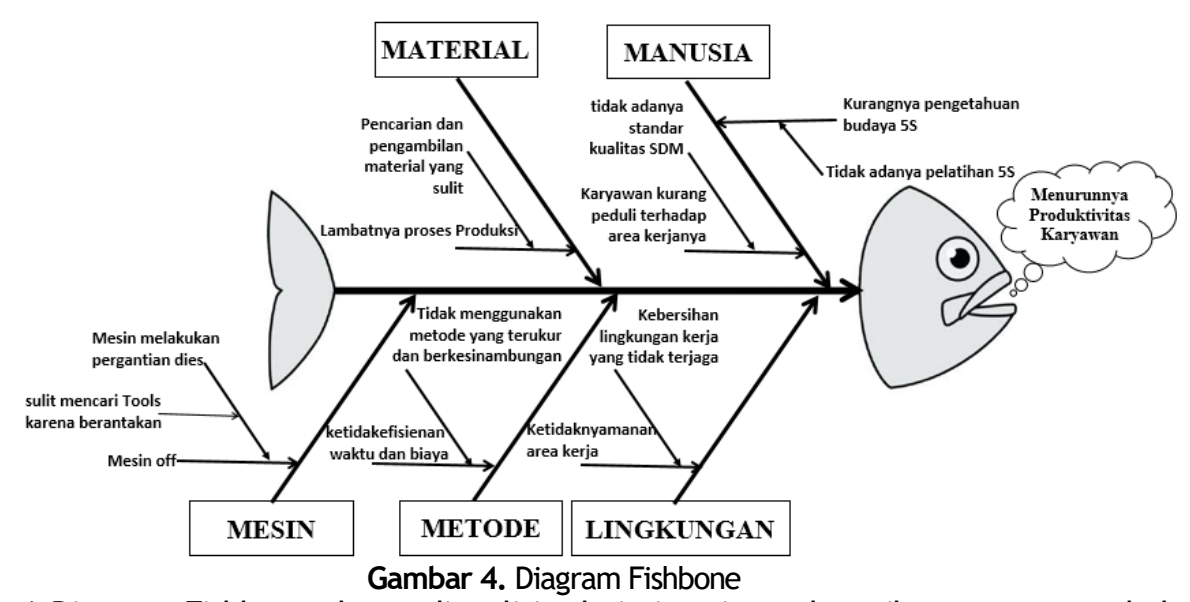

Dari Gambar 4 Diagram Fishbone dapat dianalisis dari tiap-tiap tulang ikan atau penyebab terjadinya menurunya produktivitas karyawan. Setelah dilakukan analisis dengan diagram Fishbone maka dapat diketahui kemungkinan-kemungkinan yang menyebabkan pekerjaan menjadi lama untuk pembuatan produkproduk dari proses stamping. Untuk mesin, material, manusia dan lingkungan terjadi karena faktor manusia/karyawan dalam bekerja. Untuk metode tidak adanya penggunaan metode yang terukur dan berkesinambungan karena tidak efisien pada waktu dan biaya disebabkan karena tools yang sulit dicari/berantakan sehingga harus dibuat tempat tools untuk memudahkan mengambil dan mencari tools yang ingin digunakan tanpa membutuhkan waktu lama saat mencari. 


\subsection{Analisis $5 \mathrm{~W}+1 \mathrm{H}$}

Sebagai tolak ukur untuk menganalisis kondisi yang ada, maka dihubungkan dengan beberapa faktor yakni manusia (man), mesin (machine), material, metode dan lingkungan menggunakan analisis $5 \mathrm{~W}+1 \mathrm{H}$. Hasil analisis yang diperoleh dapat dilihat pada tabel sebagai berikut:

1. What (Apa?) Permasalahan yang sedang dihadapi adalah menurunnya produktivitas karyawan dan kurangnya kedisiplinan pada karyawan.

2. Where (Dimana?) Permasalahan ini terjadi di lingkungan kerja produksi pada proses stamping di CV Widjaya Presisi.

3. When (Kapan?) Permasalahan ini sudah lama berlangsung sampai saat ini.

4. Who (Siapa?) Permasalahan ini melibatkan bagian metode dan produksi.

5. Why (Mengapa?) Permasalahan tersebut terjadi karena kurangnya kedisiplinan pada karyawan dan kurangnya fasilitas untuk karyawan bekerja.

6. How (Bagaimana?) Untuk menyelesaikan masalah yang terjadi maka kedisiplinan pada karyawan dan kurangnya fasilitas untuk karyawan bekerja tersebut harus diperbaiki.

Dari analisis yang telah dilakukan untuk mencari akar masalah yang menyebabkan menurunnya produktivitas karyawan. Alasannya adalah bahwa banyak dari waste ini terjadi karena penempatan komponen dan alat yang terlalu jauh dari lingkungan kerja, serta penempatan material yang ditempatkan dengan rapi dan tidak teratur sama sekali, sehingga menyebabkan banyak waste of motion yang muncul dan menyebabkan pekerja cepat lelah karena proses ini. Belum adanya sistem kerja yang baik, tata letak ruangan yang masih berantakan, kebersihan yang belum terjaga, dan kepedulian terhadap keamanan yang masih rendah. Kemudian juga masalah penempatan dokumen dan arsip tanpa pelabelan yang jelas, sehingga waktu untuk mencari dokumen dan arsip lama tidak terhindarkan, oleh karena itu masalah mendasar ini menyebabkan waktu proses produksi menjadi terlalu besar dan penurunan produktivitas kinerja karyawan. Oleh karena itu berdasarkan masalah yang ada, dalam penelitian ini menggunakan metode $5 \mathrm{~S}$ untuk menyelesaikan nmasalah untuk hasil yang lebih baik. Karena permasalahan banyak menyangkut mengenai faktor manusia atau karyawan dan keamanan karyawan tersebut.

\subsection{Perancangan Program 5S}

Perancangan 5S dilakukan dengan urutan kegiatan sebagai berikut:

\subsubsection{Perancangan Seiri (Ringkas)}

Yaitu untuk menyisihkan barang-barang yang tidak diperlukan dengan yang diperlukan atau menyisihkan dan membuang barang-barang yang tidak perlu di tempat kerja. Berikut ini langkah-langkah yang akan dilakukan sebelum melakukan perancangan seiri pada lingkungan kerja di lingkungan kerja produksi pada proses stamping di CV Widjaya Presisi:

1. Menentukan kriteria barang yang diperlukan dan tidak diperlukan. Kriteria barang berdasarkan frekuensi pemakaiannya dapat dilihat pada Tabel 1.

Tabel 1. Kriteria Barang Berdasarkan Frekuensinya

\begin{tabular}{|c|l|l|}
\hline Frekuensi & \multicolumn{1}{|c|}{ Kriteria } & \multicolumn{1}{|c|}{ Metode Penyimpanan } \\
\hline Rendah & $\begin{array}{l}\text { Barang yang diperlukan lebih dari 6 } \\
\text { bulan. }\end{array}$ & $\begin{array}{l}\text { Diletakkan jauh-jauh dari lingkungan kerja atau } \\
\text { dibuang. }\end{array}$ \\
\hline Sedang & Barang yang digunakan 2-6 bulan. & $\begin{array}{l}\text { Simpan disekitar area kerja yang sekiranya akan } \\
\text { digunakan. }\end{array}$ \\
\hline Tinggi & $\begin{array}{l}\text { Barang yang digunakan setiap hari, } \\
\text { minggu atau bulan. }\end{array}$ & $\begin{array}{l}\text { Simpan dan letakkan di area kerja yang mudah } \\
\text { dijangkau dan diambil saat ingin menggunakannya. }\end{array}$ \\
\hline
\end{tabular}

2. Memisahkan barang yang diperlukan dan tidak diperlukan.

3. Menentukan tindakan yang dilakukan untuk masing-masing barang berdasarkan frekuensi pemakaian.

3.3.2 Perancangan Seiton (Rapi)

Yaitu mengatur alat kerja termasuk dokumen dan arsip yang digunakan dengan rapi dan sepenuhnya menghilangkan kegiatan pencarian sehingga mereka dapat dengan mudah ditemukan dengan cepat. Berikut ini adalah langkah-langkah yang diambil dalam mengimplementasikan Seiton:

1. Menentukan barang/tools yang akan disimpan dengan lokasi yang tepat.

Berikut usulan tempat tools untuk tempat penyimpanan peralatan produksi dapat dilihat pada Gambar 5. 

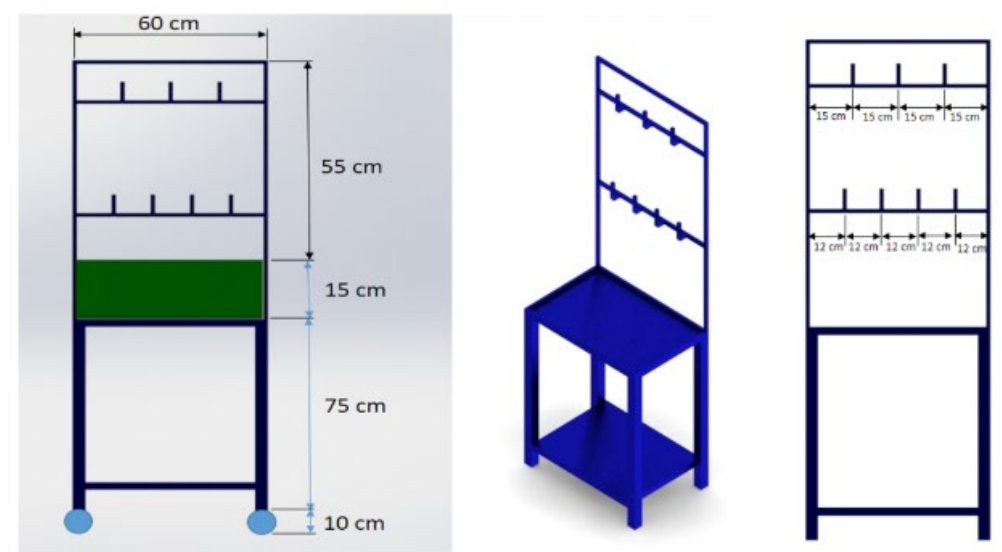

Gambar 5. Perancangan Tempat Tools

2. Menganalisa barang/tools yang akan disimpan.

3. Mengambil data barang yang ada di lingkungan kerja pada proses stamping.

4. Menentukan tindakan yang diambil dalam melakukan penataan.

\subsubsection{Perancangan Seiso (Resik)}

Yaitu menjaga kebersihan tempat kerja dalam hal lantai, barang, bangunan dan alat yang ada di lingkungan kerja. Tujuan dari perancangan seiso adalah untuk menciptakan lingkungan kerja yang bersih karena kebersihan lingkungan kerja secara tidak langsung juga dapat mempengaruhi kinerja setiap karyawan yang bekerja di lingkungan kerja. Berikut ini adalah langkah-langkah yang diambil dalam mendesain Seiso:

1. Menyediakan alat kebersihan dalam jumlah yang memadai dan kualitas yang cukup.

2. Melakukan kegiatan kebersihan di lingkungan kerja secara rutin. Kegiatan yang perlu dilakukan untuk mewujudkan kondisi resik, sebagai berikut:

- Membuang sampah pada tempatnya.

- Menyiapkan tempat sampah di setiap sudut lingkungan kerja.

- Menyediakan peralatan kebersihan yang cukup dan kualitas yang memadai.

- Setiap karyawan berpartisipasi menjaga kebersihan dan melakukannya secara rutinitas di tempat kerja masing-masing, karena tidak adanya petugas kebersihan.

- Pengadaan program kebersihan sebelum memulai aktivitas bekerja. Hal ini berarti setiap akan memulai pekerjaan baik pagi maupun sore dilakukan pembersihan tempat kerja. Dengan aktivitas ini setiap orang terlibat dalam $5 \mathrm{~S}$.

\subsubsection{Perancangan Seiketsu (Rawat)}

Yaitu mempertahankan seiri, seiton, dan seiso sehingga dapat berlangsung terus-menerus. Kemudian pertahankan kondisi yang ada sesuai standar. Berikut ini adalah langkah yang dilakukan dalam perancangan Seiketsu:

1. Standarisasi tempat kerja.

Standarisasi tempat kerja dilakukan dalam bentuk pengaturan tata letak tempat kerja bersama dengan peralatan kerja yang digunakan.

2. Poster $5 \mathrm{~S}$

Pembuatan poster ini adalah untuk memotivasi karyawan untuk selalu melakukan budaya kerja $5 \mathrm{~S}$ baik di lingkungan kerja maupun dalam kehidupan sehari-hari dan diletakkan dekat dengan pintu masuk. Adapun desain poster $5 \mathrm{~S}$ dapat dilihat pada Gambar 6.

3. Biasakan prosedur $5 \mathrm{~S}$ dalam kegiatan sehari-hari.

Prosedur yang dimaksud adalah tugas dan tanggung jawab setiap karyawan yang terkait dengan penerapan $5 \mathrm{~S}$ harus mematuhi dan menerapkannya. 


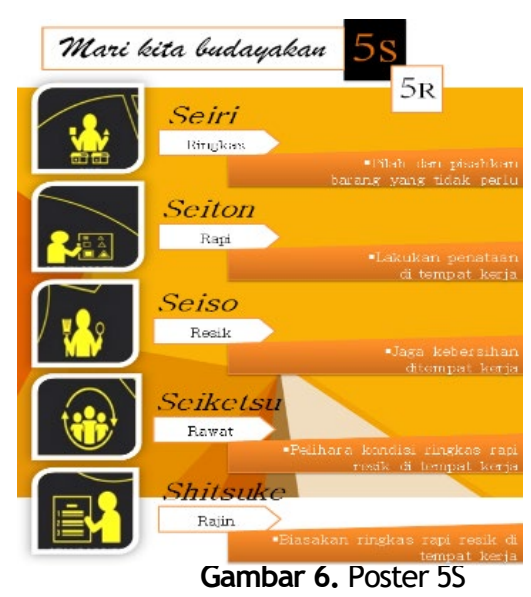

\subsubsection{Perancangan Shitsuke (Rajin)}

Yaitu sebagai suatu disiplin dan benar-benar menjadi kebiasaan, sehingga pekerja terbiasa mematuhi aturan dan diadakan penyuluhan kepada pekerja untuk bekerja secara profesional dan mewujudkan $5 \mathrm{~S}$ sebagai budaya kerja dalam kegiatan sehari-hari.

Langkah-langkah yang harus diambil dalam menerapkan Shitsuke adalah sebagai berikut:

1. Inspeksi Mingguan

Pemeriksaan pembersihan dilakukan oleh kepala produksi setiap minggu. Ini memperhitungkan kondisi kebersihan dan kerapihan tempat kerja. Adapun checksheet mingguan pada CV Widjaya Presisi dapat dilihat pada Gambar 7.



Gambar 7 Checksheet Mingguan

2. Memberikan peraturan yang tegas kepada setiap karyawan yang melanggar.

\subsection{Evaluasi Hasil}

\subsubsection{Evaluasi Dampak Terhadap Kondisi Lingkungan Kerja}

Untuk mengetahui hasil implementasi $5 \mathrm{~S}$, maka harus dilakukan evaluasi. Evaluasi dilakukan menggunakan dua acara. Cara pertama adalah dengan membandingkan foto sebelum dan sesudah pengimplementasi pada setiap sisi CV Widjaya Presisi. Apabila lingkungan kerja tampak berbeda, lebih bersih dan rapi maka penanaman budaya $5 \mathrm{~S}$ dapat dikatakan berjalan dengan baik. Apabila yang terjadi adalah lingkungan kerja tampak sama saja dengan kondisi sebelumnya, maka dapat dikatakan penanaman budaya kerja tersebut belum berjalan dengan baik dan kurangnya kesadaran karyawan.

a. Pelaksanaan Seiri (Ringkas) 
Buang semua barang yang tidak diperlukan, terutama di area produksi agar kegiatan produksi tidak terganggu. Item yang tidak digunakan di area produksi dipilih terlebih dahulu dengan memilih barang yang masih terpakai dan yang sudah tidak terpakai berdasarkan frekuensi pemakaiannya. Barang-barang yang tidak digunakan akan mengurangi mobilitas pekerja atau operator, sehingga mengurangi produktivitas dan meningkatkan risiko kecelakaan di tempat kerja.

b. Pelaksanaan Seiton (Rapi)

Merapikan barang-barang di sekitar area produksi dan meja kerja agar lebih tertata dan tidak berantakan.

c. Pelaksanaan Seiso (Resik)

Implementasi seiso dengan menghilangkan kotoran, sampah, dan barang asing dari tempat kerja agar tetap bersih dan proses berjalan dengan baik. Sudah mulainya kesadaran karyawan akan kebersihan area kerja karena area kerja yang kotor. Sebelum karyawan memulai aktivitas kerja mereka membersihkan terlebih dahulu supaya area produksi bersih.

d. Pelaksanaan Seiketsu (Rawat)

Pada implementasi seiketsu dengan memperluas konsep kebersihan ke diri sendiri dan terus menerus mempraktikkan tiga langkah sebelumnya. Kemudian pertahankan kondisi yang ada sesuai standar. Melakukan standarisasi tempat kerja dengan memberikan peraturan agar melatih karyawan produksi yang kurang disiplin dan dibuatkan jadwal untuk pengontrolan megenai $5 \mathrm{~S}$ untuk karyawan secara bergilir. Kemudian membuat poster sudah dilakukan diletakkan ditempat yang sering terlihat oleh karyawan supaya setiap karyawan melihat akan teringat program $5 \mathrm{~S}$ tersebut dan selalu mematuhi serta membiasakan program $5 \mathrm{~S}$ dalam kesehariannya.

e. Pelaksanaan Shitsuke (Rajin)

Karyawan menerapkan $5 \mathrm{~S}$ melalui norma-norma kerja, standarisasi, dan kepatuhan dengan prosedur kerja. Penerapan rajin di area line produksi dengan mempertegas peraturan kerja yang sudah dibuat oleh perusahaan dan melakukan pengecekan area mingguan seperti pengecekan kebersihan, pengecekan kerapihan area, dan pengecekan barang disekitar, dan pengembalian barang setelah pemakaian yaitu dengan memberikan poin pelanggaran $5 \mathrm{~S}$ pada karyawan yang nanti di akumulasi dan jika sudah pada poin peringatan akan diberikannya surat peringatan berupa SP 1 yang mempengaruhi pada prestasi karyawan di perusahaan sehingga berujung pada pengurangan gaji karyawan dan jika masih belum efektif bisa dipertegas dengan pemutusan kontrak atau pengeluaran karyawan. Penerapan rajin pada bagian tempat tools dengan memeriksa kondisinya setiap minggunya seperti memeriksa kondisi tools apakah masih tersusun rapi dan juga memeriksa kebersihannya.

\subsection{Penghematan Waktu Kerja}

Setelah melakukan perbaikan menggunakan $5 \mathrm{~S}$ hasil yang didapatkan dirangkum berupa penghematan waktu yang disajikan pada Tabel 2 dan Tabel 3.

Tabel 2. Hasil Perbaikan

\begin{tabular}{|c|c|c|}
\hline No & Perbaikan pada- & Waktu (min) \\
\hline 1 & Pencarian material & $5 \min$ \\
\hline 2 & $\begin{array}{l}\text { Pencarian tools saat } \\
\text { pergantian dies }\end{array}$ & $5 \mathrm{~min}$ \\
\hline 3 & $\begin{array}{l}\text { Beresiko material } \\
\text { tercampur dan tertukar }\end{array}$ & $5 \mathrm{~min}$ \\
\hline 4 & Perkakas rentan rusak & - \\
\hline 5 & Penataan yang kurang & - \\
\hline \multicolumn{2}{|r|}{ Total } & $15 \mathrm{~min}$ \\
\hline & Total dalam 2 Shift & $30 \mathrm{~min}$ \\
\hline
\end{tabular}

Tabel 3. Perbandingan sebelum dan setelah Perbaikan

\begin{tabular}{|c|c|c|c|}
\hline No & Nama Proses & $\begin{array}{l}\text { Waktu } \\
\text { (min) }\end{array}$ & Keterangan \\
\hline 1 & $\begin{array}{ll}\text { Produksi } & \text { proses } \\
\text { Stamping } & \end{array}$ & 420 min & \multirow{3}{*}{$\begin{array}{l}\text { Sebelum } \\
\text { Perbaikan }\end{array}$} \\
\hline 2 & $2 \times$ shift & $840 \mathrm{~min}$ & \\
\hline & Sub total & $840 \mathrm{~min}$ & \\
\hline 1 & Perbaikan 5S & -30 min & \multirow{2}{*}{$\begin{array}{c}\text { Setelah } \\
\text { Perbaikan }\end{array}$} \\
\hline & Total & $810 \min$ & \\
\hline
\end{tabular}

\subsection{Perbandingan Produktivitas}

Seperti yang diuraikan sebelumnya dampak dari penerapan program 5S di CV Widjaya Presisi dirasakan oleh seluruh karyawan. Mereka bekerja secara efektif dan lebih efisien. Hal ini pun membawa pengaruh yang baik dan positif terhadap hasil produksi pada proses stamping tersebut. Berikut perhitungan produktivitas pada bulan Maret dan April 2019.

- Perhitungan produktivitas pada bulan Maret 2019 adalah:

$$
\text { Produktivitas }=\frac{155081}{156298} \times 100 \%=99,2 \%
$$

- Perhitungan produktivitas pada bulan April 2019 adalah: 


$$
\text { Produktivitas }=\frac{100542}{100542} \times 100 \%=100 \%
$$

Berikut diagram Pareto produktivitas dari kinerja karyawan pada bulan Maret dan April 2019 setelah dilakukan penerapan 5S dengan diagram Pareto berwarna merah seperti terlihat pada Gambar 8.

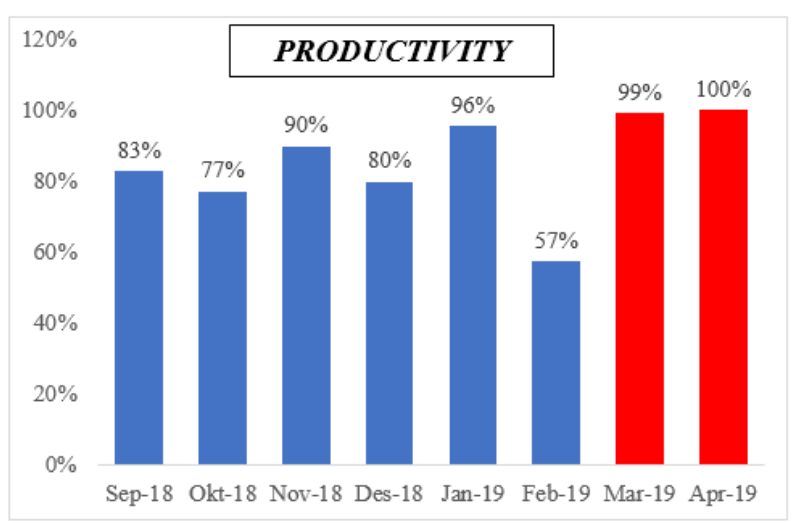

Gambar 8. Produktivitas Sebelum dan Sesudah Penerapan $5 S$

\section{Kesimpulan Dan Saran}

\subsection{Kesimpulan}

Bahwa untuk meningkatkan produktivitas di CV Widjaya Presisi dapat dimulai dengan melakukan implementasi $5 \mathrm{~S}$ sehingga dapat mengatasi masalah pada waste of motion yang terjadi pada lingkungan kerja produksi dari proses stamping. Tindakan perbaikan yang meliputi $5 \mathrm{~S}$ sebagai berikut:

a. Seiri: Dengan memilih barang yang diperlukan dan tidak diperlukan yang ada di CV Widjaya Presisi.

b. Seiton: Mengatur alat kerja termasuk dokumen dan arsip yang digunakan dengan rapi dan sepenuhnya menghilangkan kegiatan pencarian sehingga mereka dapat dengan mudah ditemukan dengan cepat tanpa melakukan waste of motion yang berakibat pada menambah waktu proses.

c. Seiso: menjaga kebersihan tempat kerja dalam hal lantai, barang, bangunan dan alat yang ada di lingkungan kerja.

d. Seiketsu: Mempertahankan seiri, seiton, dan seiso dengan memberikan SOP dan peraturan yang jelas.

e. Shitsuke: Menerapkan kedisiplinan pada setiap karyawan CV Widjaya Presisi dan melakukan inspeksi mingguan yang dilakukan oleh kepala produksi.

\subsection{Saran}

Analisis yang dilakukan hanya untuk mendukung penerapan $5 \mathrm{~S}$ diperusahaan tanpa membahas aspek-aspek lain yang terkait dengan penggunaan variabel lain. Maka untuk penelitian selanjutnya diharapkan membahas aspek-aspek lain yang terkait dengan kegunaan 5S tersebut untuk mengurangi waste yang terjadi di lingkungan kerja sehingga produktivitas kerja meningkat.

\section{Daftar Pustaka}

1. Haizer, Jay, \& B.R. (2014). Prinsip-Prinsip Manajemen Operasi. Riset Manajemen \& Akuntansi, 5(9), $26-27$.

2. Heizer, Jay \& Render, B. (2017). Operations Management (Manajemen Operasi). Operations Management (Manajemen Operasi), 7(1), 15-22.

3. Listiani, T. (2014). Penerapan Konsep 5S dalam Upaya Menciptakan Lingkungan Kerja yang Ergonomis di STIA LAN Bandung. Jurnal Ilmu Administrasi., 7(3), 214.

4. Purwanggono, P, Ruminta, R dan Irawati, S. (2014). Analisis Faktor-faktor Yang Memengaruhi Motivasi Karyawan Dalam Menerapkan Budaya Kerja 5 S (Studi Kasus Pada Karyawan PT. PLN (PERSERO) P3JB APP Semarang). Jurnal Sains, Teknologi Dan Industri. Prosiding SNATIF., 14(1), 57-65.

5. Risma. (2016). Analisis Penerapan Konsep 5 S di Bagian Proses Maintenance PT. Traktor Nusantara. Jurnal Teknik Industri, 2(2), 114.

6. Siagian, S. P. (2014). Kiat Meningkatkan Produktivitas Kerja. Riset Manajemen \& Akuntansi, 5(9), 27.

7. Widianti, T. (2015). Implementasi 5S untuk Optimalisasi Keselamatan, Kesehatan, dan Performa Kerja. Jurnal Teknik Industri, 2(2), 114. 